Volume 7

Number 1 Spring 2016 (Special Issue)

Article 2

4-11-2016

\title{
Birth of the Pipes: The Organ from its Beginnings through the Baroque Era
}

Joshua D. Drake

Cedarville University, jdrake@cedarville.edu

Follow this and additional works at: https://digitalcommons.cedarville.edu/musicalofferings

Part of the Musicology Commons, and the Music Performance Commons

DigitalCommons@Cedarville provides a publication platform for fully open access journals, which means that all articles are available on the Internet to all users immediately upon publication. However, the opinions and sentiments expressed by the authors of articles published in our journals do not necessarily indicate the endorsement or reflect the views of DigitalCommons@Cedarville, the Centennial Library, or Cedarville University and its employees. The authors are solely responsible for the content of their work. Please address questions to dc@cedarville.edu.

\section{Recommended Citation}

Drake, Joshua D. (2016) "Birth of the Pipes: The Organ from its Beginnings through the Baroque Era," Musical Offerings: Vol. 7 : No. 1 , Article 2.

DOI: $10.15385 / j m o .2016 .7 .1 .2$

Available at: https://digitalcommons.cedarville.edu/musicalofferings/vol7/iss1/2 


\section{Birth of the Pipes: The Organ from its Beginnings through the Baroque Era}

\section{Document Type}

Article

\section{Abstract}

The purpose of this presentation is to survey the development of the organ, which is one of the most magnificent and impressive musical instruments known to man. The main objective is also to explain how and why the organ developed the way that it did. Further, the presentation will attempt to answer the following questions: what deficiencies in the performance of early organs were organ builders trying to improve on, what differences in sound did they want new organs to be able to produce, and how did the needs and preferences of organists influence changes in organ design? The majority of the research for this presentation centers on the scholarly contributions of C.A. Edwards, C. F. Abdy Williams, and Willi Apel. Specifically, the focus is placed on the designs and construction of a wide variety of organs. Hopefully, this presentation will result in a clear understanding of the distinctions between these instruments and the related pros and cons.

\section{Keywords}

Organ, Baroque, instrument design, hydraulus, organa magna, organa parva, Ninfale, bellows, Johann Sebastian Bach

\section{Creative Commons License}

\section{(c)}

This work is licensed under a Creative Commons Attribution-Noncommercial-No Derivative Works 4.0 License. 


\title{
Birth of the Pipes: The Organ from Its Beginnings through the Baroque Era
}

\author{
Joshua D. Drake \\ Cedarville University
}

he organ is one of the most magnificent and impressive
musical instruments known to man. It is often referred to as
the "king of instruments." By the Baroque era, some organs were massive enough to fill up several stories of a cathedral. Such organs were the largest instruments on the planet. However, as great and wondrous as the Baroque organ was, it did not begin that way. It began as a rather small instrument that could be moved without much trouble. Over the centuries, musicians, engineers, and architects saw shortcomings in their contemporary organs and sought new ways to improve them.

To be clear, the strengths and weaknesses of a particular organ were directly related to the intended purpose of that instrument. As distinct musical cultures developed throughout Europe, new uses for organs were also developed. As a result, the rate of organ production increased. This increase in turn produced a growing number of organists. As these organists became more skilled and grew in their knowledge of the instrument, their tastes for a "high-quality" organ became more refined. Also, as the basic design of organs became more solidified, organ-builders were able to hone in on specific modifications they desired to make.

The design of the Baroque organ is the result of over two thousand years of development. This design developed primarily, for three reasons: a desire for different types of sound production in terms of pitch, range of volume, and timbre, a desire for different types and sizes

\footnotetext{
${ }^{1}$ C. A. Edwards, Organs and Organ-building: A Treatise on the History and Construction of the Organ, from its Origin to the Present Day, with Important Specifications (London: "The Bazaar" Office, 1881), 3.
}

Musical Offerings, vol. 7, no. 1, pp. 15-26. ISSN 2330-8206 (print); ISSN 2167-3799 (online);

(C) 2016, Joshua D. Drake, licensed under CC BY-NC-ND (http://creativecommons.org/licenses/by-nc-nd/3.0/) 
of organs that would fit well in specific ensembles or musical venues, and a desire to make it easier for organists to utilize the performance capabilities of the instrument.

The long story of the organ's development rightly begins with an ancient Alexandrian man by the name of Ctesibius. Employed as a barber's apprentice, Ctesibius became very familiar with large mirrors that pivoted on stands. These stands incorporated counterweights that moved up and down in tubes. The man observed that when a weight fell through a tube, air was pushed out the end of the tube. Ctesibius then held a flute to the end of a tube, let the weight fall, and discovered that this action sounded the flute. Intrigued, the barber then sought to create an instrument out of this mechanism. The first issue to solve was finding a way to sustain the air pressure and thus, the sound.

A solution was found with the use of water. With the knowledge that water always seeks to maintain a certain level, Ctesibius made a bronze cone and turned it upside down in a container of water. A tube was then attached to the inside of the cone to supply air, while a flute was placed at the cone's opening. As soon as air was blown into the cone, the water would work to push back up and force the air out of the cone. This air then moved into the flute and produced sound. Therefore, the sound could be sustained as long as someone blew into the cone. This invention became known as the hydraulus or "water organ." The instrument fascinated everyone who saw and heard it.

As captivating as this invention was, people soon looked for ways to improve it. The main drawback of the first hydraulus was that it could only produce one pitch. Heron of Alexandria enlarged the blowing system, replaced the single flute with a row of flutes, and fashioned a keyboard to control the supply of air. Now air could be sent through the flutes by pressing the keys. The sound could be immediately stopped by releasing the keys. The row of flutes was tuned to the musical scale in use and, for the first time, the hydraulus could create melodic music. ${ }^{2}$ This is an example of an innovation intended to improve the organ's ability to produce a variety of sounds.

It may be surprising that one of the first patrons of the organ was the cruel Emperor Nero. He was one of the most skilled musicians of his

\footnotetext{
${ }^{2}$ C. F. Abdy Williams, "Evolution of the Organ," Music \& Letters 5, no. 3 (July 1924): 253-254, www.jstor.org/stable/726785.
} 
day and became intrigued with the hydraulus. Nero proposed that slides be added to the bottoms of the flutes so that the sound could be "started" and "stopped." These slides were then connected to iron keys by strings or levers. Up to this point, it was very difficult to control the sound of the organ. With this brilliant design modification, the organ became easier to control as one played.

The emperor also observed that the instrument was very suitable for accompanying the voice. However, it was far too soft to be included in a large band. The hydraulus would easily be drowned out by the other instruments. Nero desired that the hydraulus would be added to the pantomime orchestra. Therefore, he set out to find a way to increase the air pressure and volume the hydraulus could produce. The emperor funded the construction of many different organs in his attempt to develop a louder sound. However, Nero did not live to see (and hear) the success of his patronage. Although he was obsessed with the organ and its improvement, apparently, it was not important enough to give him the desire to keep living. J. F. Rowbotham explains:

It is not a little curious that the last recorded act of this tyrant on earth, before his death and overthrow, should neither be a political measure, nor a monstrous crime, nor an unheard-of vice, but a simple and single-minded effort for the advancement of music. We learn that he spent the day before his death "walking about among scores of organs, all made agreeably to his directions, testing, trying, and amending them, and by all means endeavouring to secure their perfection.

The next morning, Rome was invaded and Nero committed suicide.

Some time after Nero died in 68 B.C., his organ builders were able to execute his plans and develop a system of pumps which produced a stronger, steadier current of air. This, in turn, created a louder, more powerful organ. The instrument could now be heard clearly in bands. ${ }^{3}$ This is an excellent example of a modification to better suit the organ to a specific ensemble.

${ }^{3}$ J. F. Rowbotham, "The Early History of the Organ," Musical Times and Singing Class Circular 29, no. 548 (Oct. 1, 1888): 585-586, www.jstor.org/stable/3360121. 
In continuation of the pursuit of greater volume, organ builders began to connect multiple pipes to each key on the manual. This started with a few pipes per key, but by the tenth century, there were ten pipes for every key. As time went on, this number increased to twenty, thirty, forty, and even fifty pipes. The sound produced by such an assembly was nothing short of thunderous. This loud volume could not be diminished at all.

There is some debate regarding the exact dates, but the use of bellows was introduced to the organ as early as A.D. 120. The idea for this innovation came from a blacksmith's bellows. Blowers would send air into the bellows and then stand on them to force the air into the organ. This became the distinction between the hydraulus and the organ. Specifically, this instrument became known as the pneumatic organ. ${ }^{4}$ The hydraulus employed water pressure while the organ used weighted bellows. The need for air in an organ with hundreds of pipes was so great that between twenty and forty bellows and more than twice that many strapping men to blow was necessary. Often there would be enough men to take turns blowing when one group became fatigued. There were also four huge manuals with keys that had to be played with the fists, knees, and feet. This instrument became known as the "organa magna." The downfall of this organ was that it could not be played softly; it was only capable of producing a tremendous, booming sound. Although impressive in terms of sonic power, this amount of volume did not facilitate the creation of melodic music. So it can be understood why this organ design did not last long.

In fact, the organa magna was not the only organ in production at the time. Other smaller organs were also being made, especially in England. The first was called the "organa parva" or "little organ." It was usually carried in processions and used to play interludes. Also, its range was too high to accompany vocal music. This is a prime example of an organ designed for a specific ensemble.

The second was called the Ninfale, or portative organ. This instrument was typically hung from the player's neck. The right hand activated the blowing mechanism while the left hand played the keys. ${ }^{5}$ There is also some evidence that Khalif Harun al-Rashid sent a pneumatic organ to

\footnotetext{
${ }^{4}$ Willi Apel, "Early History of the Organ," Speculum 23, no. 2 (April, 1948): 199, www.jstor.org/stable/2852952.

${ }^{5}$ C. F. Abdy Williams, 254-256.
} 
Charlemagne in 822 or 826 . This organ was built by an Arabian named Ja'far and is described as having "extraordinarily soft tone."6

By the end of the tenth century, organs were commonly found in both cathedrals and monasteries. In 951, the Bishop of Winchester acquired the largest organ in the world for his cathedral. In a poem by Mason, the instrument was described as having four hundred pipes, twenty-six bellows, and was operated by seventy men. It had two manuals with a total of forty keys and each key controlled ten pipes. Each manual was played by a separate monk. The organ was also becoming very popular in Germany, with organs built in Haberstadt and Erfurt. ${ }^{7}$ So we see that the tenth century was a time when at least a few organs were designed specifically to fit certain musical venues: cathedrals and monasteries.

When designing an organ specifically to fit inside of a cathedral, several complex factors had to be taken into consideration. The main factors were: acoustics, visual aesthetics, and liturgical requirements. Based on the construction materials used and the architectural design of a cathedral, the acoustics of its interior would have unique characteristics. These characteristics directly influenced where the organ was placed. A location which enabled the organ to benefit most from the natural acoustics of the cathedral was usually chosen. Depending on the cathedral, this might have meant placing the pipes in one of the front corners, on a side wall, in the rear, or even on the second floor. It is also important to realize that the pipes and their corresponding chests can be a considerable distance away from the console. Sadly, some building committees decided to place the pipes of the organ in a separate "organ chamber" outside of the main sanctuary. This usually had a very negative effect on the clarity and fullness of the organ's sound. ${ }^{8}$

Although the organ is primarily a musical instrument, depending on its size, it can be a prominent visual feature of a cathedral or other venue's interior architecture. The visual aesthetics that an organ contributes to a venue are determined primarily by the design of the case, its respective chests, the arrangement of the pipes, and their respective colors and artistic ornamentation. For instance, pipes could be made of gold,

\footnotetext{
${ }^{6}$ Henry George Farmer, The Organ of the Ancients: From Eastern Sources (Hebrew, Syriac and Arabic) (London: W. Reeves, 1931), 140.

${ }^{7}$ Edwards, 7-9.

${ }^{8}$ Blanton, Joseph E, The Organ in Church Design (Albany, TX: Venture Press, 1957), 69-71.
} 
silver, clay, tin, wood, ivory, ebony, or even alabaster. The latter materials were rare, but the point is that the materials used directly influenced the overall appearance of an organ and, therefore, whether or not it would fit the design of a venue. ${ }^{9}$

As far as liturgical requirements go, the organ was typically used to perform music in the Catholic mass or protestant liturgy. It was often used to accompany the church's choir. For this reason, organs were usually placed next to the choir or over the choir stalls. As organs became progressively larger, organ-builders began constructing them on the choir-screen. Arthur Hill highly recommends this, saying:

For a large church we strongly advise the placing of the organ on the quire-screen. There are many advantages in this position. The instrument is free from any obstacle which would be detrimental to its acoustical effect, while it has the opportunity of displaying its case, which, in this position, should certainly be a good one. The choir is, moreover, able to have the full advantage of its accompaniment, which is not the case when the west-end site is chosen. ${ }^{10}$

Considering Hill's statement, each individual organ would have to be specially designed to fit the unique interior dimensions of a given cathedral. If the cathedral was large and had a large quire-screen, there should be plenty of room to build a grand, highly-decorated organ. On the other hand, if the cathedral was only large enough to hold two hundred people, a smaller organ would have to be designed to fit the available space.

Up until the conclusion of the eleventh century, each note of the organ was controlled by a separate lever. The hydraulus had a keyboard that could be played with the fingers, but the organ did not. ${ }^{11}$ Then, in the late 1000s, an organ was constructed at Magdeburg, in Saxony. This instrument included a keyboard that spanned two octaves. However, the keys were not like those of more modern organs. The keys of this medieval organ were several inches wide and rounded at the end.

\footnotetext{
${ }^{9}$ Hill, Arthur George, The Organ-cases and Organs of the Middle Ages and Renaissance (London: D. Bogue, 1883), 42-43.

${ }^{10}$ Ibid., $19-20$.

${ }^{11}$ C. F. Abdy Williams, 256.
} 
Despite its deficiency in terms of fitting the average human hand, and thus, being easier to play, the organ at Magdeburg was still an improvement in pitch range.

It was also during this time that the stops of the organ were reinvented. Again, the hydraulus possessed stops, but the earliest organs did not. Before this development, the volume of the organ was almost completely uncontrollable. Because of this, in the thirteenth century, Catholic priests in Greece and Rome actually banned organ playing in the church. With the addition of stops, however, the player could choose between several different groups of pipes of various lengths, thus creating different harmonies, timbres, and volumes. Also, by the eleventh century, the hydraulus had become almost completely extinct and was replaced by the organ.

By the sixteenth century, the organ had been greatly refined. The size of the keys had been decreased in two stages: first, so that one hand could reach up to five notes, then again so it could reach an octave. A new type of pipe was also added to the instrument's design. These updated pipes emitted sound through the use of a thin sliver of metal or wood, not with a whistle. They became known as reeds and produced sounds similar to wind instruments such as the oboe and trumpet.

New stops were also added that caused a wide variety of events to occur. Not only were there stops that rang small bells, but some stops even caused birds to sing and roosters to crow. Others made figures of men pop up in the windows of the organ case. Some of the stops were used to set a great variety of case decorations in motion, such as: giants' heads, gargoyle-like figures, and priests with monkey faces. ${ }^{12}$

A great tragedy in the development of the organ occurred in England in the second half of the seventeenth century. Leading up to this time, there had been arguments in the church concerning the use of the organ to accompany and "guide" congregational singing. Many held that the congregation should be able to sing without any aid from instruments. Others observed that many in the congregation were considerably lacking in musical skill, thus contributing very unpleasant sounds to the singing. Then, following the death of Charles I of England, the British government decided that the cathedral service should be ended altogether. Along with it, Parliament declared that, "all organs and the

${ }^{12}$ Ibid., 259. 
frames wherein they stood should be taken away and defaced and none hereafter set up in their place." The cathedrals of England were now at the mercy of Oliver Cromwell and his army. Only a few organs from this period survived the destruction that ensued.

When Charles II was restored to the throne in 1660, work quickly began to restore the cathedral service. By this point, there were only four organ builders left. Forced to work in the carpentry business, they had unfortunately become very rusty at constructing organs. Therefore, foreign organ builders were summoned from across the continent. Responding to this call, Renatus Harris, an Englishman from Paris, and "Father" Smith, of Germany, traveled to Britain. "Father" Smith then built the organ in St. Paul's Cathedral. These men were closely followed by many other organ builders. This influx of builders led to a substantial number of advancements in organ design, most of which were made by the British. ${ }^{13}$

One such Englishman invented concussion bellows, which keep the air flow consistent when the player changes volume suddenly. Without these new bellows, the organ would briefly go out of tune whenever a sudden change took place. A sudden change in hand position on a manual is hard to execute with a light touch. Because of this, organ music either had to be relatively slow, or composers would just have to accept part of their piece sounding pitchy. This meant that lack of concussion bellows in an organ was seen as a big problem. Without them, composers basically had two choices: write easier, more simple music, or be content with their piece only being performed when a highly-skilled organist was in town. Even then, somewhat questionable pitch quality was almost unavoidable.

Another design modification came in the form of pedals. Organbuilders recognized the importance of designing organs with pedals as early as the fourteenth century. The original purpose of a pedal was to allow the organist to sustain a drone or pedal point of a fugue with his foot. This freed both of his hands to play the subject, episodes, and other ornamented sections of fugues with excellence. Before the addition of the pedal, performing such polyphonic works on an organ would not sound nearly as impressive.

${ }^{13}$ Ibid., 261-2. 
For example, the low bass notes included in much polyphonic organ music are incredibly important to create a full, powerful sound. Some organ-designers considered making the manuals extend farther to the left to cover the lower register. However, this modification would be almost pointless by itself. If an organist could not afford to hold a bass note with his left hand, the notes to be played above would sound unsupported. Or, depending on the rate of a piece's harmonic progression, reaching far to the left on a wider manual could be incredibly difficult. But with some kind of sustain pedal available, the organist could simply hold a bass note with his foot. This allowed him to devote the rest of his physical, mental, and emotional energy to performing the rest of the notes. Pedal claviers and pedal organs were constructed in Beeksow in 1418. Actually, Pretorius claimed that organs were constructed with pedals in Halberstadt as early as 1359. T. Casson describes the value of the pedal this way:

The old builders were much cleverer fellows than their modern successors seem to think them. Mr. Abdy Williams considers that in 1470 a German organ without pedals would have been considered more remarkable than one furnished with them. Be this as it may, there can be no doubt but that the pedals provided means for extrication from what I must call the dilemma of organ-playing, besides, perhaps, providing convenient distribution over the physical powers of the performer, of the excessive labour is even yet distributed in carillon playing. ${ }^{14}$

So it is clear that the pedal was a crucial addition to the organ in terms of making performances less work and more musically excellent. An Englishman designed composition pedals, enabling the organist to change stops with his feet. ${ }^{15}$ More and more pedals continued to be added to the organ throughout the next several centuries.

One of these additions was the development of the swell pedal, which eventually led to the swell organ. It was created by Jordan in $1772 .{ }^{16}$ He simply placed some of the organ's pipes in a box that could be

\footnotetext{
${ }^{14}$ Casson, Thomas, Lecture on the Pedal Organ: Its History, Design and Control (London: W. Reeves, 1911).

${ }^{15}$ C. F. Abdy Williams, 263.

${ }^{16}$ No last name is given for Jordan in Organs and Organ-building.
} 
opened and shut by a foot pedal. This produced a "swelling" or diminishing in the volume of the pipes. ${ }^{17}$ The invention of the organ's swell pedal was both an advance in the organ's capability to produce a variety of volumes and, simultaneously, an advance in the ease with which organists could achieve outstanding performances.

The organ continued to reach new heights in performance capabilities throughout the eighteenth century. Any paper on the history of the Baroque organ would be terribly incomplete if it did not mention the great organist, composer, and church musician, Johann Sebastian Bach. Bach played a variety of different organs during his lifetime. That being said, he never explicitly stated what his preferred characteristics were for an organ. However, some general conclusions can be made based on the organs Bach played, how he composed for them, and a few organ-reports he wrote. One such report, from a rebuilding project at Muhlhausen in 1708, lists a few elements Bach considered necessary: good bass tone (specifically deep pedal stops), some particular stops in addition to the principal chorus (Fagotto 16', Viola da gamba 8', Nasat, a row of bells 4'), a coupler between the main manual and Brustwerk, and a well-regulated Tremulant, which most likely affected all three manuals. ${ }^{18}$

These preferences are all related primarily to the particular sounds the organ could produce and the ease with which it could be played. This shows what was most important to J. S. Bach. Indeed, the variety and quality of sounds and the capability to effectively utilize them was very important to any professional organist. However, leading up to the Baroque era, the design of the organ was modified for more than one reason. The organ's design was modified for three reasons: a desire for different types of sound production, a desire for different types and sizes of organs, and a desire to make it easier for organists to utilize the instrument's full potential. These were the reasons that led to the creation of the magnificent Baroque organ.

\footnotetext{
${ }^{17}$ Edwards, 21.

${ }^{18}$ Williams, Peter. "Johann Sebastian Bach's Ideal Organ," Organists' Review 94, no. 2: 7-13. Academic Search Complete, EBSCOhost (accessed September 23, 2015).
} 


\section{Bibliography}

Ambrosino, Jonathan. "Achieving a Breathtaking Benchmark." Choir \& Organ 13, no. 1 (January 2005): 60. MasterFILE Premier, EBSCOhost (accessed September 23, 2015).

Apel, Willi. "Early History of the Organ." Speculum 23, no. 2 (April, 1948): 191-216. www.jstor.org/stable/2852952.

Audsley, George Ashdown. The Art of Organ-building; A Comprehensive Historical, Theoretical and Practical Treatise on the Tonal Appointment and Mechanical Construction of Concert-room, Church, and Chamber Organs. New York: Dodd, Mead, and Company, 1905. . Organ-stops and their Artistic Registration; Names, Form, Construction, Tonalities, and Offices in Scientific Combination. New York: The H.W. Gray Co., 1921.

Blain, Denis. "Use of Pneumatic Force in Pipe Organ Building." Journal of American Organbuilding 27, no. 1 (March 2012): 26. Vocational Studies Premier, EBSCOhost (accessed September 22, 2015).

Blanton, Joseph E. The Organ in Church Design. Albany, TX:

Venture Press, 1957.

Casson, Thomas. Lecture on the Pedal Organ: Its History, Design and Control. London: W. Reeves, 1911.

Dickson, W. E. Practical Organ-Building. London: C. Lockwood and Co., 1882.

Edwards, C. A. Organs and Organ Building: A Treatise on the History and Construction of the Organ, from its Origin to the Present Day, with Important Specifications. London: "The Bazaar" Office, 1881.

Farmer, Henry George. The Organ of the Ancients: From Eastern Sources (Hebrew, Syriac and Arabic). London: W. Reeves, 1931.

Fisk, Charles. "The Organ's Breath of Life." The Diapason, (September 1969): 18-19.

www.cbfisk.com/sites/default/files/cbf_writings/cbf_writings 03.pdf.

Hamilton, James Alexander, and Joseph Warren. Hamilton's Catechism of the Organ. Buren, The Netherlands: F. Knuf, 1992.

Harvey, Sidney W. "A Short History of the Organs of Canterbury Cathedral." The Musical Times 57, no. 884 (October 1, 1916): 448-452. www.jstor.org/stable/910216. 
Hill, Arthur George. The Organ-cases and Organs of the Middle Ages and Renaissance. London: D. Bogue, 1883.

Ortloff, Jonathan. "A Magnet for Every Pipe." Journal of American Organbuilding 29, no. 4 (December 2014): 8-13. Vocational Studies Premier, EBSCOhost (accessed September 22, 2015).

Rowbotham, J. F. "The Early History of the Organ.” The Musical Times and Singing Class Circular 29, no. 548 (October 1, 1888): 585-589. www.jstor.org/stable/3360121.

Williams, C. F. Abdy. "The Evolution of the Choir Organ." The Musical Times 48, no. 767 (January 1, 1907): 18-21. www.jstor.org/stable/903805. . "Evolution of the Organ." Music \& Letters 5, no. 3 (July 1924): 253-263. www.jstor.org/stable/726785.

Williams, Peter. "Johann Sebastian Bach's Ideal Organ." Organists' Review 94, no. 2 (May 2008): 7-13. Academic Search Complete, EBSCOhost (accessed September 23, 2015).

Williams, Peter F. A New History of the Organ from the Greeks to the Present Day. Bloomington: Indiana University Press, 1980. 